\title{
$K$. radicincitans, a beneficial bacteria that promotes radish growth under field conditions
}

\author{
Beatrice Berger $^{1}$ - Melanie Wiesner ${ }^{1} \cdot$ Anita K. Brock $^{1}$ - Monika Schreiner ${ }^{1}$. \\ Silke Ruppel ${ }^{1}$
}

Accepted: 18 June 2015 / Published online: 24 July 2015

(C) INRA and Springer-Verlag France 2015

\begin{abstract}
Conserving arable soils is a major challenge in agronomy. Using beneficial native microorganisms such as plant growth-promoting bacteria contributes to sustainability in agricultural systems and helps maintain stable yields and product quality. However, the growth-promoting effects of candidate strains observed in pot trials often disappear under field conditions. Therefore, we studied here the bacterial colonization of Kosakonia radicincitans, a known plant growthpromoting bacteria, and the effect of $K$. radicincitans on radish. We measured plant growth and glucosinolate profile when plants were grown under glasshouse and field conditions. $K$. radicincitans cells were applied onto seeds or plants when two leaves had emerged. Our results show an increase of up to $25 \%$ of leaf and tuber weights of inoculated radish plants under glasshouse and field conditions, compared to non-inoculated plants. Glucosinolate contents remained unchanged, except when leaves were sprayed with $K$. radicincitans. We also found that $K$. radicincitans suppressed aromatic 2-phenylethyl glucosinolates in leaves. To sum up, we demonstrate for the first time the capability of $K$. radicincitans to persist and promote plant growth in a member of the Brassicaceae family under field conditions. Therefore, $K$. radicincitans is a promising candidate for further processing as a growth-promoting product in sustainable agriculture.
\end{abstract}

Keywords Kosakonia radicincitans · DSM 16656 · Plant growth-promoting bacteria $\cdot$ Raphanus sativus . Glucosinolate profile

Beatrice Berger

bergerb@igzev.de

1 Leibniz Institute of Vegetable and Ornamental Crops e.V., Theodor-Echtermeyer-Weg 1, 14979 Grossbeeren, Germany

\section{Introduction}

Beneficial microorganisms such as plant growth-promoting bacteria (PGPB) are found to strengthen plant growth and increase yield without loss of quality. Therefore, PGPB are attractive for sustainable plant cultivation and inoculants based on beneficial strains have been developed. Among commercially applied bacterial species are varieties of Agrobacterium, Azospirillum, Azotobacter, Bacillus, and Pseudomonas (Glick 2012). In an attempt to identify potential PGPB in the Northern Hemisphere, Kosakonia radicincitans was isolated from winter wheat; after establishing cultivation of the strain under laboratory conditions, biological atmospheric nitrogen-fixing and phytohormone-producing ability was demonstrated (Ruppel and Merbach 1995). Due to changes in the bacterial taxonomy of the genus Enterobacter and reclassification processes, the strain DSM 16656, formerly known as Pantoea agglomerans or Enterobacter radicincitans (Kämpfer et al. 2005), is now designated as the strain $K$. radicincitans, a member of the newly defined genus Kosakonia (Brady et al. 2013).

Systemic application of $K$. radicincitans on glasshousegrown plants revealed significant growth-promoting effects on various vegetables. Shoot, root, and tuber growth of kohlrabi (Brassica oleracea) increased by up to 47,36 , and $37 \%$, respectively (Ruppel et al. 2006). Moreover, root or shoot growth of 5-week-old tomato plants (Solanum lycopersicum) increased by up to 80 or $50 \%$ (Berger et al. 2013), which emphasized $K$. radicincitans' role as potent $\mathrm{PGPB}$ for various vegetables.

Although plant pot studies provide information on the potential of beneficial bacterial strains, requirements for bacterial use in agriculture must be tested in the field, as endorsed recently (Glick 2012). To minimize the risk of PGPB failure and to determine conditions for PGPB success, a twofold strategy combining fundamental research on bacterial 
mechanisms and an intensive survey on the PGPB of interest under different plant growing conditions seems reasonable.

PGPB use various strategies for plant promotion, such as suppressing plant disease by competitive colonization, improving nutrient uptake, or stimulating phytohormone production (Glick 2012). In pure bacterial culture and in leaf and root sap of winter wheat, $K$. radicincitans cells were shown to fix atmospheric nitrogen (Ruppel and Merbach 1995), produce phytohormones (auxin-like compounds such as indole-3-lactic acid and indole-3-acetic acid and cytokininlike compounds such as N6-isopentyladenosine and N6isopentyladenine) (Scholz-Seidel and Ruppel 1992), and solubilize calcium phosphate (Schilling et al. 1998). Bacteria and plants are challenged by a constantly changing environment. Knowledge about which environmental factors boost or inhibit bacterial beneficial properties for plants will decide on the success of PGPB in field cultivation. Nevertheless, mechanisms involved in PGPB functions are not fully deciphered in detail.

Members of the Brassicaceae family are economically important crops, characterized by a group of secondary metabolites called glucosinolates. Glucosinolates and their hydrolyzed breakdown products not only create the typical flavor of Brassica species but also serve as mediators in plant-insect (Giamoustaris and Mithen 1997) and plant-pathogen (Pedras and Hossain 2011) interactions, although their role in plant growth regulation is controversially discussed (Redovnikovic et al. 2008). Some studies indicate that indole glucosinolates are linked to the plant growth hormone indole-3-acetic acid (IAA) (Ljung et al. 2002).

$K$. radicincitans is able to colonize aerial parts of various brassicaceous plants when grown in growth chambers. It was discovered that the colonization by $K$. radicincitans was mediated by the glucosinolate profile. The bacterial colonization in the phyllosphere was affected by its aromatic and aliphatic glucosinolate pattern (Schreiner et al. 2009). It is known that a plant's glucosinolate profile is strongly regulated by ecophysiological factors, such as nutrition and water availability (Verkerk et al. 2009), and biotic stressors (Halkier and Gershenzon 2006). To date, nothing is known about how conditions in the field impact the growth-promoting effect of $K$. radicincitans in Brassicaceae species. Glucosinolates might be synthesized in different concentrations and compositions as a result of the plant-PGPB relationship.

Here, we continued and intensified former studies on PGPB-Brassicales interactions (Schreiner et al. 2009; Brock et al. 2013) to bridge the current gap of knowledge about $K$. radicincitans colonization behavior, performance, and its impact on glucosinolate patterns, both under field and glasshouse conditions, to minimize the risk of PGPB failure in agricultural practice. Therefore, we tested whether bacterial application influenced plant growth and especially tuber formation of radish (Raphanus sativus L. var. sativus) under glasshouse and field conditions. Furthermore, we quantified the colonization and persistence of our target bacteria. We also determined the bacterially mediated change on the glucosinolate profile and concentration in radish leaf and tuber, assuming activation of chemical defense.

\section{Material and methods}

\subsection{Plant and bacterial material}

Radish (R. sativus L. var. sativus) seeds cv. Rondar (F1 Hybrid; S \& G GmbH, Kleve, Germany) were used in all experiments. Seeds were surface sterilized with a $10 \%$ sodium hypochlorite solution for $5 \mathrm{~min}$ and rinsed four times in sterile water before further treatment.

K. radicincitans (DSM 16656) colonies were maintained on ENDO agar (Merck, Darmstadt, Germany) at $4{ }^{\circ} \mathrm{C}$. For all experiments, $K$. radicincitans cells were grown in standard nutrient solution (Merck, Darmstadt, Germany) in a rotary incubator $(100 \mathrm{rpm})$ at $29^{\circ} \mathrm{C}$ for $24 \mathrm{~h}$. Cells were spun down at $8000 \mathrm{rpm}$ for $20 \mathrm{~min}$ and washed with $0.05 \mathrm{M} \mathrm{NaCl}$ to completely remove all nutrients from the growth media; the procedure was repeated two times before inoculation. The bacterial cell density of $10^{7}$ and $10^{8}$ cells $\mathrm{ml}^{-1}$ was adjusted as needed in $0.05 \mathrm{M} \mathrm{NaCl}$.

\subsection{Glasshouse pot experiments}

Inoculation of radish was performed as follows: (a) seeds were incubated with a $0.05 \mathrm{M} \mathrm{NaCl}$ (control) solution or with a $10^{7} \mathrm{cfu} \mathrm{ml}^{-1}$ of K. radicincitans solution for $2 \mathrm{~min}$, and (b) seedlings at the two-leaf stage were sprayed with a solution of $0.05 \mathrm{M} \mathrm{NaCl}$ (control) or $10^{7}$ bacterial cells per plant (Fig. 1). Seeds were placed in pots filled with 1.51 of $1: 1(v / v)$ sand/soil mixture of Fruhlsdorfer Erde/Quarzsand and randomly placed on trivets to avoid transfer of bacteria between single pots. Seedlings were irrigated and fertilized manually with Hoagland solution (Hoagland and Arnon 1950). Plants were harvest 5 weeks after germination. Temperature and humidity were recorded over the growth period, with an average temperature of $17{ }^{\circ} \mathrm{C}$ in 2010 and $20{ }^{\circ} \mathrm{C}$ in 2011 and with an average air humidity of $87 \%$ in 2010 and $63 \%$ in 2011 .

\subsection{Field experiments}

Field experiments were conducted at the field plot in Grossbeeren, Germany (52 $\left.20^{\prime} \mathrm{N}, 13^{\circ} 19^{\prime} \mathrm{E}\right)$ (Fig. 1, right panel). Field plots ( $5.4 \mathrm{~m}^{2}$ each) were established on a loamy sandy soil in a randomized block design. Seed bed preparation and weed control using Butisan ${ }^{\circledR}$ (BASF, Limburgerhof, Germany) $\left(11 \mathrm{ha}^{-1}\right)$ were followed by drilling radish seeds cv. Rondar with a distance of $2 \mathrm{~cm}$ within the lane and a lane 


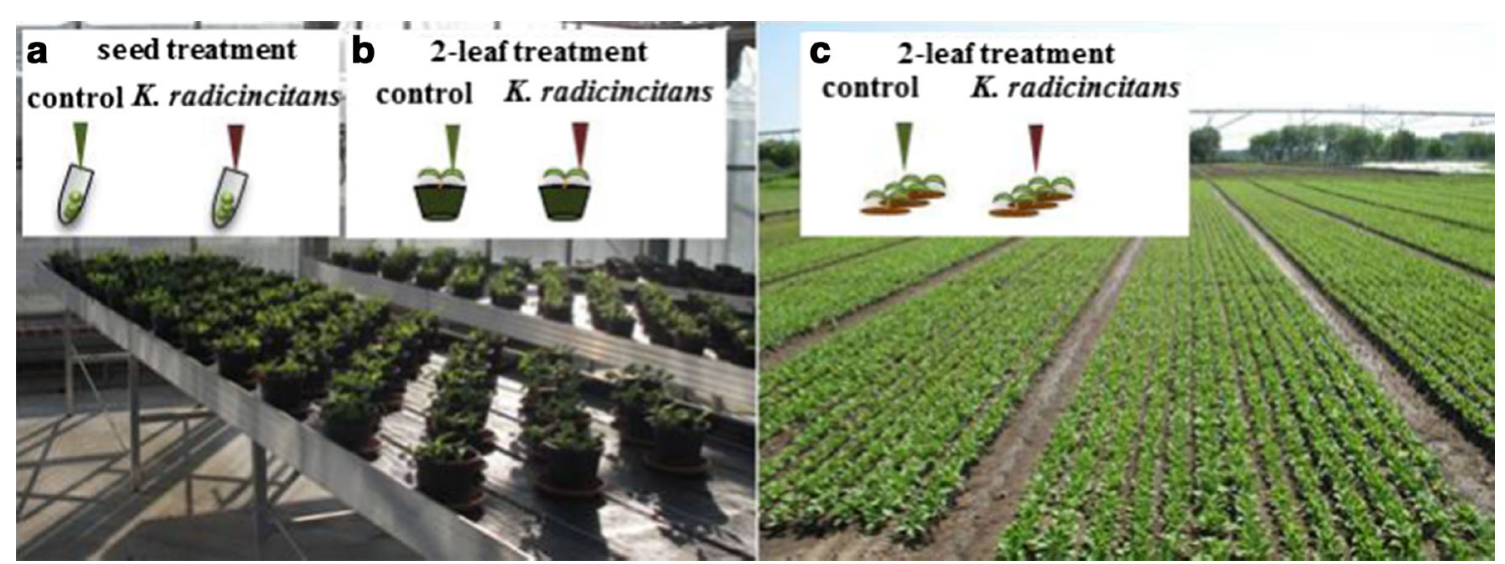

Fig. 1 Kradicincitans colonization analyzed under both glasshouse and field conditions. Left glasshouse-grown radish plants inoculated with $10^{7}$ Kosakonia radicincitans cells per plant $a$ applied before germination or $b$ applied at two-leaf stage and their respective controls inoculated with

distance of $13 \mathrm{~cm}$. Plants were regularly irrigated using the BEREST-90 program. Application of $0.05 \mathrm{M} \mathrm{NaCl}$ or $10^{8} \mathrm{cfu} \mathrm{ml}^{-1} \mathrm{~K}$. radicincitans was performed at the twoleaf stage by pouring the solutions on the plants. We choose a higher concentration of bacteria in the field application than in the glasshouse experiments to counteract unpredictable dilution effects. Five weeks after germination, $1 \mathrm{~m}^{2}$ of radish plants from the center of each plot was harvested. Total fresh mass of tuber and leaf material of each plot was measured. Twenty radish plants per plot were randomly chosen to determine leaf and tuber fresh and dry weight as well as the tuber diameter of those plants. Samples from three different spots per plot were taken and flash frozen for isolation of nucleic acid and glucosinolate analysis. Field experiments were conducted in May-June 2010 and 2011. Plants were harvested 5 weeks after germination according to $\mathrm{BBCH}$ code 15-16 for radish.

\subsection{Desulfoglucosinolate extraction and analysis}

Desulfoglucosinolate extraction and analysis were carried out as described recently (Wiesner et al. 2013). In short, 20-mg aliquots of leaf and tuber tissue were extracted with $750 \mu \mathrm{l}$ $70 \%(v / v)$ hot methanol and $100 \mu \mathrm{l}$ of $0.1 \mathrm{mM}$ 2-propenyl glucosinolate internal standard (BCR-367R; Community Bureau of Reference, Brussels) for $10 \mathrm{~min}$ in boiling water. Samples were then centrifuged and re-extracted. Supernatants were loaded onto DEAD-Sephadex A-25 columns conditioned with $2 \mathrm{M}$ acetic acid and with $6 \mathrm{M}$ imidazole formate solution, followed by washing with $0.02 \mathrm{M}$ sodium acetate buffer. For overnight incubation, a $75 \mu \mathrm{l}$ aryl sulfatase (Sigma-Aldrich, Steinheim, Germany) solution was added. Desulfoglucosinolates were eluted with $1 \mathrm{ml}$ Milli-Q water and analyzed by HPLC using a Merck HPLC system (Merck-Hitachi, Darmstadt, Germany) with a Spherisorb ODS2 column (Bischoff, Leonberg, Germany) with the
$0.05 \mathrm{M} \mathrm{NaCl}$. Right $c$ field-grown radish plants sprayed with $10^{8}$ $K$. radicincitans cells per plant at the two-leaf stage or $0.05 \mathrm{M} \mathrm{NaCl}$ as a control

following HPLC conditions: solvent A, Milli-Q water; solvent B, $20 \% v / v$ acetonitrile in Milli-Q water; and solvent C, $100 \%$ acetonitrile. Desulfoglucosinolates were detected at a wavelength of $229 \mathrm{~nm}$ and identified according to a glucosinolate library from previous work. Determination of desulfoglucosinolates was performed in duplicate. Desulfoglucosinolate concentration was determined in six replicates per treatment.

\subsection{Nucleic acid extraction}

Leaf and tuber samples for nucleic acid extraction were harvested 5 weeks after germination, flash frozen in liquid nitrogen, and stored at $-80^{\circ} \mathrm{C}$ until further analysis. Frozen tuber tissue was ground in liquid nitrogen in a RETSCH mill (RETSCH, Haan, Germany), and aliquots (approx. $50 \mathrm{mg}$ ) were transferred into 1.5-ml Eppendorf tubes for deoxyribonucleic acid (DNA) extraction. Genomic DNA was extracted with the DNeasy Plant Kit from Qiagen (Düren, Germany). DNA quantity and quality were checked photometrically with the NanoDrop ${ }^{\odot}$ (Thermo Scientific, Bonn, Germany) system.

\subsection{Quantification of $K$. radicincitans population density}

The 16S ribosomal DNA (rDNA) gene copy number of $K$. radicincitans was determined by real-time quantitative PCR and a TaqMan probe as described before (Ruppel et al. 2006) using the following primer pair: $519 f$ (lane 1991) and E.radr (5'-CGT GGA CTA CCA GGG TAT CTA ATC-3') and the fam-labeled probe ([6-FAM] CTC CCC ACG CTT TCG CAC CTG AGC [BHQ-6-FAM]). The copy number of the $16 \mathrm{~S}$ rDNA gene of $K$. radicincitans was expressed as a relative value using the gene copy number of actin as a reference. The LeActin primer pair (Penninckx et al. 1996) was chosen to amplify actin. PCRs for 16S rDNA and LeActin were performed using the SYBR Green qPCR kit (Bio-Rad, 
Munich, Germany). All measurements were performed in triplicates on a CFX96 machine (Bio-Rad, Munich, Germany).

\subsection{Statistics}

Data were analyzed using the SigmaPlot 12.3 software. Normality was tested using the Kolmogorov-Smirnov test followed by one-way or two-way ANOVA.

\section{Results and discussion}

The benefit of PGPB in sustainable plant cultivation is indisputable. Nevertheless, for each potential beneficial strain, the challenge is to establish reliable values in crop cultivation systems. To provide information on the potential of $K$. radicincitans for commercial use, we performed a study on radish under glasshouse and field conditions. We tested the bacterial effect on plant growth and yield and associated this to bacterial capability to colonize the plant and alter the plant glucosinolate pattern under various growth conditions (Fig. 1). In summary, we found that $K$. radicincitans promotes growth in radish plants and suppresses aromatic glucosinolates in $K$. radicincitans-inoculated leaves.

\subsection{K. radicincitans promotes growth in glasshouse- and field-grown radish plants}

Generally, plant growth promoted by $K$. radicincitans was observed in all radish plants inoculated with the bacteria compared to plants that were not inoculated (Fig. 2a). In glasshouse pot experiments, tuber and leaf weight was $50 \%$ greater than that in the respective control plants when radish seeds were inoculated with $K$. radicincitans directly before germination. In contrast, the increase in tuber and leaf weight in bacteria-treated plants at the two-leaf stage was only 25 or $20 \%$ (Fig. 2b). The total weight increase was doubled in seed-inoculated plants compared to two-leaf sprayed plants. In line with weight gain, the diameter of the radish tuber was also increased by $K$. radicincitans $(P<0.001)$ (Fig. 2c).

When $K$. radicincitans was applied to the aerial part of young kohlrabi plants growing in glasshouse chambers, the plants increased their dry matter leaf and tuber material by $36 \%$ (Ruppel et al. 2006). In kohlrabi plants, a similar percentage of weight gain was detected for leaf and tuber material, whereas in radish plants, we found a greater weight increase for tubers over leaves in inoculated plants.

Interestingly, radish plants gained more weight if they were exposed to the bacteria from germination rather than when leaves were sprayed as two leaves emerged (Fig. 2b). Therefore, exposure time seems to determine the magnitude of growth increase. Differences in nitrogenase activity could be an explanation, since higher nitrogenase activity was detected in wheat sap when seeds where treated with $K$. radicincitans before germination compared to plants treated when two leaves had emerged (Scholz-Seidel and Ruppel 1992).

In a second setup, we conducted field experiments and treated plants at the two-leaf stage to test the applicability of the bacteria under field conditions. So far, $K$. radicincitans has been tested in a field study on winter wheat and pea. In that context, the grain yield gain in six different winter wheat cultivars growing under field conditions was demonstrated to be up to $20 \%$ higher when plants were inoculated with K. radicincitans (Remus et al. 2000). Moreover, bacteriatreated peas increased dry matter yield by about $100 \%$ on a loamy sandy soil (Höflich et al. 1992). Kloepper and Schroth (1978) described several potential PGPB tested on radish plants growing in glasshouse pot experiments using clay loam from field sides. Astonishing increases in radish growth of up to $500 \%$ were shown by some of the bacteria they used. However, in the field, the effects of the bacteria were lowered by more than $50 \%$. Although the growth-promoting potential of $K$. radicincitans in our experiments appears to be small compared to the findings of Kloepper and Schroth (1978), the drastic decline of $50 \%$ in weight gain of bacteria-treated field-grown plants as observed by Kloepper and Schroth did not occur in our study.

To evaluate the bacterial impact on radish yield, we harvested $1 \mathrm{~m}^{2}$ from each of 12 replicated plots from the respective treatment. Over two consecutive years, we found 14 $23 \%$ more tuber mass and 20-23\% more leaf mass when plants were treated with bacteria $(P<0.001)$ (Fig. 2 d), similar to the findings in winter wheat.

It seems that $K$. radicincitans also retains the growthpromoting traits observed in glasshouse experiments under field conditions. However, to maximize the growthpromoting potential of $K$. radicincitans and for easy handling, a bacterial application before germination might be preferred. Schoebitz et al. (2013) reviewed the formulation of a process for encapsulating microbial inoculates, which could improve soil-plant fertilization with microbial products. In our study, we directly treated seeds with $K$. radicincitans cells and demonstrated in a glasshouse pot experiment the potential of seed inoculation methods, which now have to be verified under field conditions.

\subsection{Glucosinolate profile in $K$. radicincitans-inoculated radish}

Only a few reports investigate the effect of PGPB on glucosinolate synthesis (O'Callaghan et al. 2000; Bending and Lincoln 2000). We therefore measured glucosinolates in leaf and tuber material of radish plants that were inoculated with $K$. radicincitans compared to non-inoculated control plants at the time of harvest. We detected indolic indol-3-ylmethyl (glucobrassicin), 4-methoxy-indol-3-ylmethyl (4-methoxy- 
Fig. 2 K. radicincitans promotes plant growth in inoculated radish plants. a Glasshouse-grown radish plants either inoculated with a $0.05 \mathrm{M} \mathrm{NaCl}$ control solution or $10^{7} \mathrm{cfu} \mathrm{ml}^{-1}$ $K$. radicincitans cells before germination. b Fresh mass of leaves and tuber of glasshouseand field-grown radish plants inoculated with $0.05 \mathrm{M} \mathrm{NaCl}$ (control, light green/pink bars) or $10^{7}$ (glasshouse) $/ 10^{8}$ (field)cfu $K$ radicincitans cells (K. radicincitans, dark green/red bars) before germination (seed treatment) or when two leaves had emerged (two-leaf treatment), $n=$ 10-20. c Tuber diameter of glasshouse- and field-grown radish plants inoculated with $0.05 \mathrm{M} \mathrm{NaCl}$ (control, pink circles) or $10^{7} \mathrm{cfu}$

$K$. radicincitans cells

( $K$. radicincitans, red circles), $n=$ 8-10 tubers. d Effect of $K$. radicincitans on tuber and leaf yield in field experiments. Asterisks indicate statistically significant differences between control and $K$. radicincitansinoculated plants. $* P<0.05$; $* * P<0.01 ; * * * P<0.001$

\section{a}

\section{Kosakonia radicincitans treated radish plants}

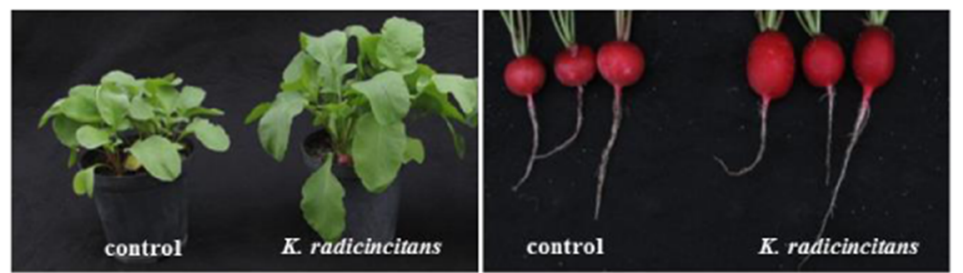

b

Fresh mass (g) per plant

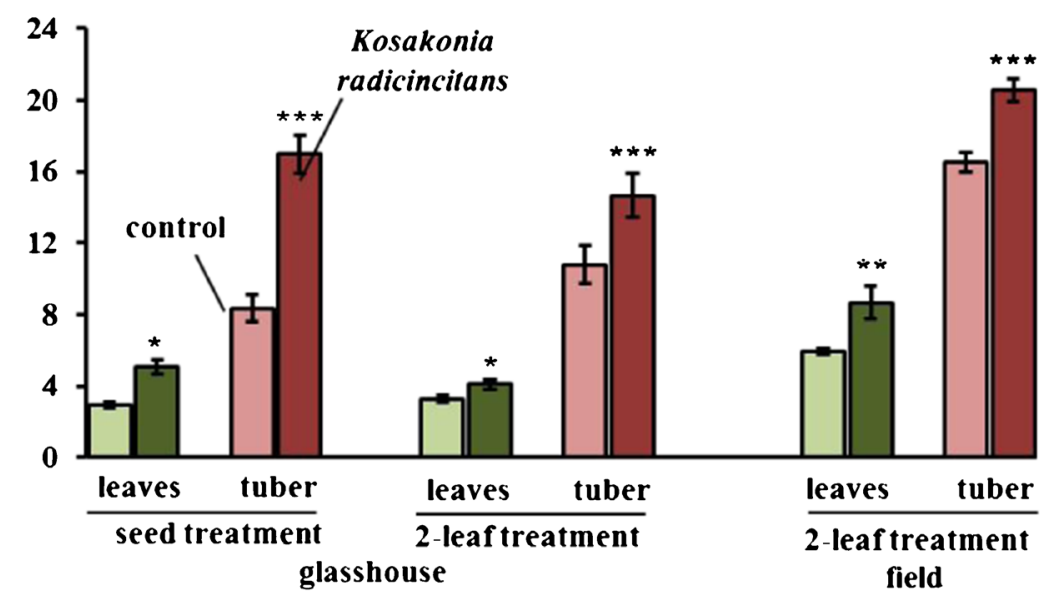

C Diameter tuber (mm)

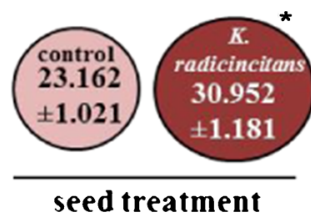

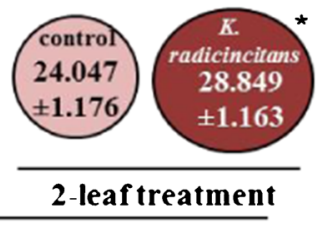

2-leaf treatment

glasshouse

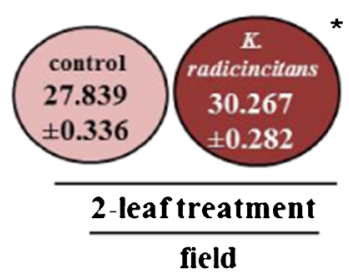

field d

Effect of Kosakonia radicincitans on tuber and leaf yield in field experiments

\begin{tabular}{|c|c|c|c|c|c|c|}
\hline \multirow[t]{2}{*}{ year } & \multicolumn{2}{|c|}{ tuber yield $\left(\mathrm{kg} \mathrm{qm}^{-1}\right)$} & \multirow{2}{*}{$\begin{array}{l}\text { increase of } \\
\text { tuber yield } \\
(\%)\end{array}$} & \multicolumn{2}{|c|}{ leaf yield $\left(\mathrm{kg} \mathrm{qm}^{-1}\right)$} & \multirow{2}{*}{$\begin{array}{l}\text { increase of } \\
\text { leaf yield } \\
(\%)\end{array}$} \\
\hline & control & K. radicincitans & & control & K. radicinci & \\
\hline 2010 & $1586 \pm 79.6$ & $2057 \pm 143.8^{\star}$ & 23 & $633 \pm 79$ & $794 \pm 38.1^{*}$ & 20 \\
\hline 2011 & $2447 \pm 49.5$ & $2850 \pm 91.4^{\star}$ & 14 & $1031 \pm 26.1$ & $1333 \pm 41.2^{\star}$ & 23 \\
\hline
\end{tabular}

glucobrassicin), 1-methoxy-indol-3-ylmethyl (neoglucobrassicin), and aliphatic 4-methylsulfinylbutyl (glucoraphanin), 2hydroxy-4-pentenyl (gluconapoleiferin), 5 methylsulfinylpentyl (glucoalyssin), 3-butenyl (gluconapin), 4-pentenyl (glucobrassicanapin), 4-methylthiobutyl (glucoerucin), 7-methylthioheptyl, and 2-hydroxy-3-butenyl glucosinolate (progoitrin). Most abundant glucosinolates found in the tubers were glucoraphanin and glucoerucin, and in the leaves, they were glucoraphanin and glucobrassicin.
The only detectable aromatic glucosinolate was 2phenylethyl (gluconasturtiin).

Former studies on potted Brassica species showed no changes in glucosinolate concentration in their leaves when inoculated with $K$. radicincitans (Schreiner et al. 2009). Likewise, we found no statistically significant differences between inoculated leaves and their respective controls in glasshouseand field-grown radish plants (Fig. 3), except for the aromatic glucosinolate 2-phenylethyl in leaves, with lower 
Fig. 3 Suppression of aromatic glucosinolates by $K$. radicincitans in radish leaves. Aliphatic, indolic, and aromatic glucosinolate content of leaves and tuber in a seed inoculated and glasshouse grown; $\mathbf{b}$ potted, glasshouse grown, and inoculated at the two-leaf plant stage; or c sown in the field and inoculated at the two-leaf plant stage with either $0.05 \mathrm{M} \mathrm{NaCl}$ control solution (light bars) or with $10^{7} \mathrm{cfu} \mathrm{m}^{-1}$ (glasshouse)/ $10^{8} \mathrm{cfu} \mathrm{m}^{-1}$ (field) $K$. radicincitans cells (dark bars) per plant, $n=5-6 . * P<0.05$
Glucosinolates (GS) greenhouse - seed treatment
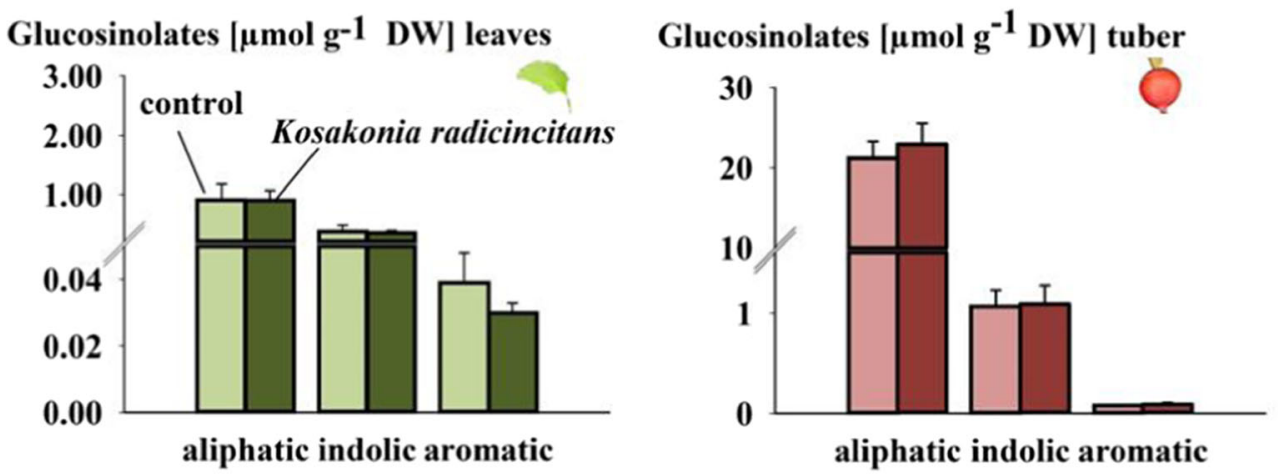

b

Glucosinolates (GS) greenhouse - 2-leaf treatment
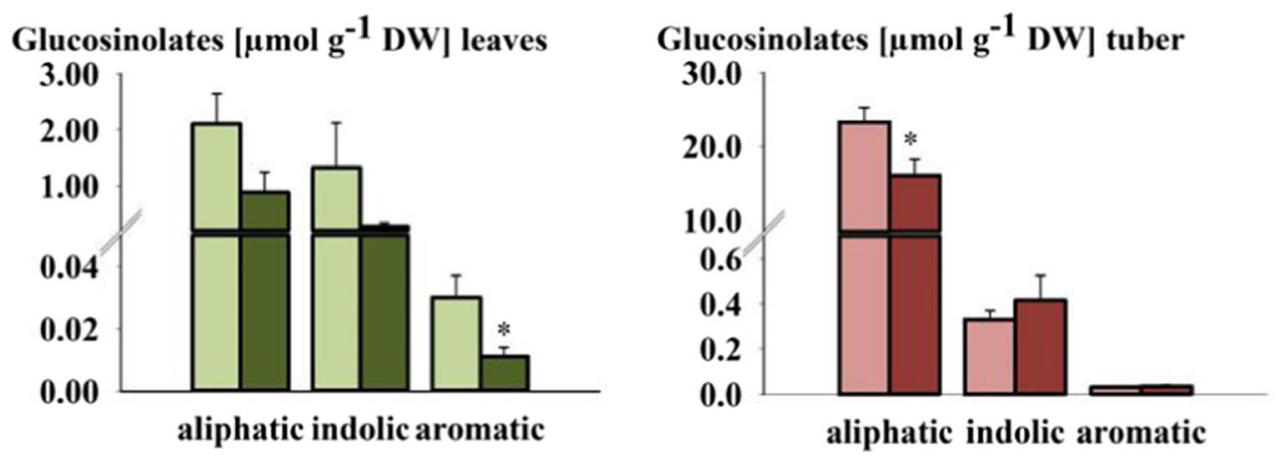

C Glucosinolates (GS) field - 2-leaf treatment

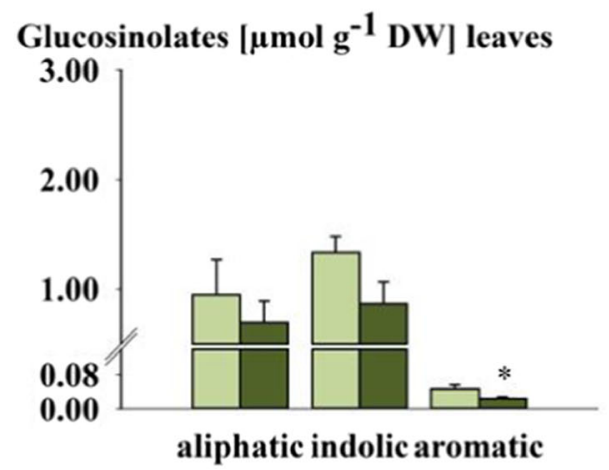

concentrations in $K$. radicincitans-inoculated plants than in the controls (Fig. 3b, c) $(P<0.05)$. In fact, these values were lower in both glasshouse- and field-grown radish plants colonized by the bacteria. Conversely, a high content of the aromatic 2-phenylethyl glucosinolate in leaves was found to be associated with a low colonization rate of $K$. radicincitans (Schreiner et al. 2009). Since 2-phenylethyl tends to simultaneously accumulate in tubers in our study, we suggest that $K$. radicincitans might cause a shift of this aromatic glucosinolate towards the rhizosphere. When glucosinolates and their corresponding breakdown product, 2-phenylethyl isothiocyanate, are rhizosecreted into the soil, they were shown to be responsible for microbial defense (Vig et al. 2009).
Hydrolyzed 2-phenylethyl glucosinolate was shown to be very toxic in vitro against major soil-borne pathogens in cereals (Sarwar et al. 1998), and a shift of 2-phenylethyl glucosinolate towards the roots might be reasonable since its hydrolysis products are more effective against pathogens in the soil (van Dam et al. 2009).

Other glucosinolates belonging to the aliphatic group already demonstrated to play an important role in the Arabidopsis-Pseudomonas pathosystem (Fan et al. 2011) were not significantly different in $K$. radicincitans-inoculated leaves compared to the control plants and showed no consistent pattern in tubers. Our findings are in contrast to recent results from Arabidopsis thaliana leaf inoculated with 
Fig. 4 Accumulation of $K$. radicincitans DNA in inoculated radish tubers. Relative $K$. radicincitans $16 \mathrm{~S}$ rDNA gene copy number in tuber tissue of non-inoculated control (pink bars) and $K$. radicincitansinoculated (red bars) radish plants grown in a glasshouse pot experiment $(G H)$ and in the field. The relative change was calculated using an actin gene copy number (LeActin PCR) as a reference, $n=4-6$
$\mathrm{X}$-fold induction of 16S rDNA-gene copy number of Kosakonia radicincitans

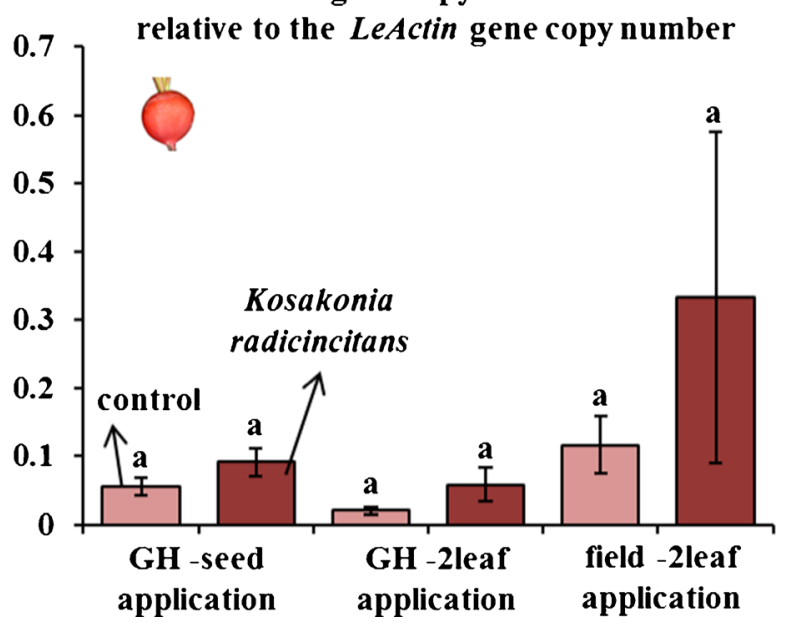

$K$. radicincitans. There, 10 weeks after inoculation with $K$. radicincitans, increased aliphatic glucosinolates were found in leaves and a potential priming role in Arabidopsis by $K$. radicincitans has been shown (Brock et al. 2013). Observed differences possibly indicate a species-specific interaction of bacterial treatment, plant age, and induction of glucosinolate biosynthesis. In contrast, the absence of altered levels of indolic glucosinolates supports findings from the Arabidopsis- $K$. radicincitans system that jasmonic acid signaling is not involved, since indolic glucosinolates were found to be induced by jasmonate (Brader et al. 2001; Wiesner et al. 2013). It seems that a plant's response to $K$. radicincitans is species specific, and whether it is a wild plant or cultivar appears to have a minor influence.

\section{3 $\mathrm{K}$. radicincitans prefers to colonize tuber tissue}

At the time of harvest, the colonization of tuber and leaf tissue by $K$. radicincitans was determined to test whether and where the bacteria persist on the plant. On the whole, $K$. radicincitans was successfully established under glasshouse as well as field conditions. However, after a period of 5 weeks, $K$. radicincitans $16 \mathrm{~S}$ rDNA mainly accumulated in the tuber tissue rather than in the aerial parts of the plant (Fig. 4). Leaves of $K$. radicincitans-treated plants were not, or only sporadically, colonized (data not shown). This is in line with findings from other inoculated vegetables (Ruppel et al. 2006; Berger et al. 2013). Whereas previous data was only obtained from pot experiments, here, we show the colonization pattern by $K$. radicincitans of both field- and potgrown plants. Changes in total bacterial population numbers were not detected in $K$. radicincitans-treated plants (data not shown). This could be due to substitution of other bacteria by $K$. radicincitans, since numbers of $K$. radicincitans were greater in inoculated plants. Moreover, at a late stage of plant development, the pattern of colonization by
$K$. radicincitans was found to be similar in plants from bacteria-treated seeds and those whose leaves had been sprayed (Fig. 4).

We conclude that the site of application has a minor influence on the long-term colonization ability. Therefore, seed treatment before germination does not seem mandatory for the success of bacterial colonization. However, pot studies in legumes showed that coating pea seeds with bacteria such as Rhizobium strains and Pseudomonas fluorescens resulted in prolonged survival times of the bacteria on the plant (Höflich et al. 1992). Whether coating induces prolonged survival times of $K$. radicincitans on plants needs to be evaluated. At the same time, it should be tested whether seed coating can further increases plant growth promotion. Therefore, seed coating studies with $K$. radicincitans are planned for the future.

\section{Conclusions}

In conclusion, we demonstrate the capability of $K$. radicincitans to colonize and persist in a member of the Brassicaceae and to promote radish growth under glasshouse as well as natural conditions. No apparent effect was found in glucosinolate content and composition after bacterial application, except for aromatic 2-phenylethyl glucosinolate levels in leaves. Therefore, $K$ radicincitans is a promising candidate for further processing, specifically biotechnological processing of $K$. radicincitans formulations for sustainable agriculture.

Acknowledgments We thank Birgit Wernitz and Juliane Gräwert for their technical assistance and the gardening team for their invaluable support in field experiments. We express gratitude to Andrea Jankowsky for her assistance in HPLC-DAD analysis. We thank the alliance Arbeitsgemeinschaft industrieller Forschungsvereinigungen e.V. and the Leibniz Institute of Vegetable and Ornamental Crops for funding. 


\section{References}

Bending GD, Lincoln SD (2000) Inhibition of soil nitrifying bacteria communities and their activities by glucosinolate hydrolysis products. Soil Biol Biochem 32(8-9):1261-1269. doi:10.1016/S00380717(00)00043-2

Berger B, Brock AK, Ruppel S (2013) Nitrogen supply influences plant growth and transcriptional responses induced by Enterobacter radicincitans in Solanum lycopersicum. Plant Soil 370(1-2):641652. doi:10.1007/s11104-013-1633-0

Brader G, Tas É, Palva ET (2001) Jasmonate-dependent induction of indole glucosinolates in Arabidopsis by culture filtrates of the nonspecific pathogen Erwinia carotovora. Plant Physiol 126(2):849 860. doi:10.1104/pp. 126.2.849

Brady C, Cleenwerck I, Venter S, Coutinho T, De Vos P (2013) Taxonomic evaluation of the genus Enterobacter based on multilocus sequence analysis (MLSA): proposal to reclassify E. nimipressuralis and E. amnigenus into Lelliottia gen. nov as Lelliottia nimipressuralis comb. nov and Lelliottia amnigena comb. nov., respectively, E. gergoviae and E. pyrinus into Pluralibacter gen. nov as Pluralibacter gergoviae comb. nov and Pluralibacter pyrinus comb. nov., respectively, E. cowanii, E. radicincitans, E. oryzae and E. arachidis into Kosakonia gen. nov as Kosakonia cowanii comb. nov., Kosakonia radicincitans comb. nov., Kosakonia oryzae comb. nov and Kosakonia arachidis comb. nov., respectively, and E. turicensis, E. helveticus and E. pulveris into Cronobacter as Cronobacter zurichensis nom. nov., Cronobacter helveticus comb. nov and Cronobacter pulveris comb. nov., respectively, and emended description of the genera Enterobacter and Cronobacter. Syst Appl Microbiol 36 (5):309319. doi: 10.1016/j.syapm.2013.03.005

Brock AK, Berger B, Mewis I, Ruppel S (2013) Impact of the PGPB Enterobacter radicincitans DSM 16656 on growth, glucosinolate profile, and immune responses of Arabidopsis thaliana. Microb Ecol 65(3):661-670. doi:10.1007/s00248-012-0146-3

Fan J, Crooks C, Creissen G, Hill L, Fairhurst S, Doerner P, Lamb C (2011) Pseudomonas sax genes overcome aliphatic isothiocyanatemediated non-host resistance in Arabidopsis. Science 331(6021): 1185-1188. doi:10.1126/science.1199707

Giamoustaris A, Mithen R (1997) Glucosinolates and disease resistance in oilseed rape (Brassica napus ssp. oleifera). Plant Pathol 46(2): 271-275. doi:10.1046/j.1365-3059.1997.d01-222.x

Glick BR (2012) Plant growth-promoting bacteria: mechanisms and applications. Scientifica 2012:15. doi:10.6064/2012/963401

Halkier BA, Gershenzon J (2006) Biology and biochemistry of glucosinolates. Annu Rev Plant Biol 57:303-333. doi:10.1146/annurev. arplant.57.032905.105228

Hoagland DR, Arnon DI (1950) The water-culture method for growing plants without soil. Circular California Agricultural Experiment Station 347 , 2nd edn., 32 pp

Höflich G, Galante F, Liste H-H, Weise I, Ruppel S, Scholz- Seidel C (1992) Phytoeffective combination effects of symbiotic and associative microorganisms on legumes. Symbiosis 14:427-438

Kämpfer P, Ruppel S, Remus R (2005) Enterobacter radicincitans sp nov., a plant growth promoting species of the family Enterobacteriaceae. Syst Appl Microbiol 28 (3):213-221. doi: 10. 1016/j.syapm.2004.12.007

Kloepper JW, Schroth MN (1978) Plant growth-promoting rhizobacteria on radishes. In: Proceedings of the 4th International Conference on Plant Pathogenic Bacteria 2:879-882

Ljung K, Hull A, Kowalczyk M, Marchant A, Celenza J, Cohen J, Sandberg G (2002) Biosynthesis, conjugation, catabolism and homeostasis of indole-3-acetic acid in Arabidopsis thaliana. Plant Mol Biol 49(3-4):249-272. doi:10.1023/A:1015298812300
O'Callaghan KJ, Stone PJ, Hu X, Griffiths DW, Davey MR, Cocking EC (2000) Effects of glucosinolates and flavonoids on colonization of the roots of Brassica napus by Azorhizobium caulinodans ORS571. Appl Environ Microbiol 66(5):2185-2191. doi:10.1128/AEM.66.5. 2185-2191.2000

Pedras MSC, Hossain S (2011) Interaction of cruciferous phytoanticipins with plant fungal pathogens: indole glucosinolates are not metabolized but the corresponding desulfo-derivatives and nitriles are. Phytochemistry 72(18):2308-2316. doi:10.1016/j.phytochem. 2011.08.018

Penninckx I, Eggermont K, Terras F, Thomma B, Samblanx G, Buchala A, Metraux JP, Manners JM, Broekaert WF (1996) Pathogeninduced systemic activation of a plant defensin gene in Arabidopsis follows a salicylic acid-independent pathway. Plant Cell 8(12):2309-2323. doi:10.1105/tpc.8.12.2309

Redovnikovic IR, Glivetic T, Delonga K, Vorkapic-Furac J (2008) Glucosinolates and their potential role in plant. Period Biol 110(4): 297-309

Remus R, Ruppel S, Jacob HJ, Hecht-Buchholz C, Merbach W (2000) Colonization behaviour of two enterobacterial strains on cereals. Biol Fert Soils 30(5-6):550-557. doi:10.1007/s003740050035

Ruppel S, Merbach W (1995) Effects of different nitrogen sources on nitrogen fixation and bacterial growth of Pantoea agglomerans and Azospirillum sp in bacterial pure culture: an investigation using $\mathrm{N}-15(2)$ incorporation and acetylene reduction measures. Microbio Res 150(4):409-418

Ruppel S, Rühlmann J, Merbach W (2006) Quantification and localization of bacteria in plant tissues using quantitative real-time PCR and online emission fingerprinting. Plant Soil 286(1-2):21-35. doi:10. 1371/journal.pgen. 1000943

Sarwar M, Kirkegaard JA, Wong PTW, Desmarchelier JM (1998) Biofumigation potential of brassicas. III. In vitro toxicity of isothiocyanates to soil-borne fungal pathogens. Plant Soil 201(1):103-112. doi:10.1023/a:1004381129991

Schilling G, Gransee A, Deubel A, Lezovic G, Ruppel S (1998) Phosphorus availability, root exudates, and microbial activity in the rhizosphere. Z Pflanzen Bodenk 161(4):465-478

Schoebitz M, Lopez MD, Roldan A (2013) Bioencapsulation of microbial inoculants for better soil-plant fertilization. A review. Agron Sustain Dev 33(4):751-765. doi:10.1007/s13593-013-0142-0

Scholz-Seidel C, Ruppel S (1992) Nitrogenase activities and phytohormone activities of Pantoea agglomerans in culture and their reflection in combination in wheat plants. Zentralbl Mikrobiol 147(5): 319-328

Schreiner M, Krumbein A, Ruppel S (2009) Interaction between plants and bacteria: glucosinolates and phyllospheric colonization of cruciferous vegetables by Enterobacter radicincitans DSM 16656. J Mol Microb Biotech 17(3):124-135. doi:10.1159/000226589

van Dam NM, Tytgat TOG, Kirkegaard JA (2009) Root and shoot glucosinolates: a comparison of their diversity, function and interactions in natural and managed ecosystems. Phytochem Rev 8(1): 171-186. doi:10.1007/s11101-008-9101-9

Verkerk R, Schreiner M, Krumbein A, Ciska E, Holst B, Rowland I, De Schrijver R, Hansen M, Gerhaeuser C, Mithen R, Dekker M (2009) Glucosinolates in Brassica vegetables: the influence of the food supply chain on intake, bioavailability and human health. Mol Nutr Food Res 53:S219-S265. doi:10.1002/mnfr.200800065

Vig AP, Rampal G, Thind TS, Arora S (2009) Bio-protective effects of glucosinolates - a review. LWT-Food Sci Technol 42(10):15611572. doi:10.1016/j.lwt.2009.05.023

Wiesner M, Hanschen FS, Schreiner M, Glatt H, Zrenner R (2013) Induced production of 1-methoxy-indol-3-ylmethyl glucosinolate by jasmonic acid and methyl jasmonate in sprouts and leaves of Pak Choi (Brassica rapa ssp. chinensis). Int J Mol Sci 14(7): 14996-15016. doi:10.3390/ijms140714996 